\title{
Determination of lactadherin concentration in dairy by-products by ELISA: Effect of heat treatment and hydrolysis
}

\author{
Daniel Ripollés, José A. Parrón, Javier Fraguas, Miguel Calvo, María D. Pérez, and Lourdes Sánchez ${ }^{1}$ \\ Departamento de Producción Animal y Ciencia de los Alimentos, Facultad de Veterinaria, Instituto Agroalimentario de Aragón (IA2) \\ (Universidad de Zaragoza-CITA), Zaragoza, Spain
}

\section{ABSTRACT}

Lactadherin is a peripheral glycoprotein of the milk fat globule membrane with several attributed biological activities. In this study, we developed an indirect competitive ELISA to determine lactadherin concentration by using a rabbit polyclonal antiserum. The ELISA was applied to quantify lactadherin in several dairy byproducts. Of the products tested, raw and commercial buttermilk had the highest concentrations of lactadherin (6.79 and $5.27 \mathrm{mg} / \mathrm{g}$ of product, respectively), followed by commercial butter serum $(4.86 \mathrm{mg} / \mathrm{g})$, commercial skim milk $(4.84 \mathrm{mg} / \mathrm{g})$, and raw whey $(1.20 \mathrm{mg} / \mathrm{g})$. The concentration of immunoreactive lactadherin was also determined in dairy by-products after they were subjected to different technological treatments. Thus, raw products were heat treated at combinations of temperature and time typically used in the dairy industry, and commercial products were hydrolyzed using 3 proteolytic enzyme preparations. Heat treatments of whey and buttermilk resulted in a smaller decrease in lactadherin concentration than did hydrolysis as determined by ELISA and electrophoresis. At high temperatures for long durations, the loss of lactadherin was higher in whey than in buttermilk, with the maximal reduction of around $48 \%$ found after treating whey at $72^{\circ} \mathrm{C}$ for $60 \mathrm{~min}$. Hydrolysis of commercial products with proteolytic enzymes resulted in a marked decrease of immunoreactivity within the first 5 min of treatment, which thereafter was constant throughout $4 \mathrm{~h}$ of hydrolysis. These results demonstrate that dairy by-products from milk fat processing are good natural sources of lactadherin, although technological processes have to be considered, because they have different effects on lactadherin content.

Key words: lactadherin, dairy by-product, heat treatment, hydrolysis

Received July 31, 2017.

Accepted September 27, 2017.

${ }^{1}$ Corresponding author: lousanchez@unizar.es

\section{INTRODUCTION}

Lipids are secreted in milk in the form of spherical droplets of about 4 to $5 \mu \mathrm{m}$ in diameter called milk fat globules. These globules are surrounded by a thin membrane known as the milk fat globule membrane (MFGM). The MFGM is derived from the apical plasma membrane of lactating mammary epithelial cells, and is composed of proteins, lipids, and other minor constituents (Lopez, 2011). Among MFGM components, proteins account for between 25 and $70 \%$ of its DM content, and isolation of MFGM proteins has gained increasing attention in recent years due to their great variety of bioactive properties (Danthine et al., 2000; Fong et al., 2007). One MFGM protein of great interest is lactadherin, which is also found in a wide range of tissues: thyroid and salivary glands, kidney, lungs, and heart (Andersen et al., 1997), and in several body fluids, such as bronchoalveolar or bile (Butler et al., 1980). Lactadherin exists in 2 glycosylation variants (PAS-6 and PAS-7), which have the same protein core of 409 AA and molecular weights of 47 and 50 $\mathrm{kDa}$, respectively, as determined by SDS-PAGE (Kim et al., 1992). The reported biological functions of lactadherin include antiviral (Parrón et al., 2016), anticoagulant (Shi and Gilbert, 2003), and anti-inflammatory (Nyegaard et al., 2013) activities.

Because of the great interest in the biological properties of MFGM proteins that could make them potential components of nutraceuticals and functional products, it is necessary to develop methods to quantify these proteins in different sources and select the best methods for their isolation. Generally, protein quantification is difficult if analytical standards are not available, as is the case for MFGM proteins (Fong and Norris, 2009; Holzmüller and Kulozik, 2016), or if the proteins are embedded in a membrane, such as the MFGM proteins butyrophilin and adipophilin (Vanderghem et al., 2011). Several techniques have been applied to estimate the concentration of MFGM proteins in dairy fractions and products. Among them, the measurement of stained electrophoretic band intensity has been extensively 
used (Ye et al., 2002; He et al., 2010; Haddadian et al., 2017). Pallesen et al. (2007) determined the concentration of mucin 15 (MUC15) in different milk fractions by measuring the intensity of the bands obtained after Western blotting, which included in-house-purified MUC15 standards. Most recently, to determine the concentration of some MFGM proteins, Fong and Norris (2009) used the absolute quantification technique (AQUA), currently applied in proteomic studies, and Holzmüller and Kulozik (2016) used a technique based on the measurement of fluorescence associated with protein bands separated by electrophoresis and their content of tryptophan. Although immunoassays have been extensively used to quantify a wide range of milk proteins (Conesa et al., 2005; Dupont et al., 2006), few studies have reported the quantification of MFGM protein concentration by using immunoassays.

Dairy products are usually subjected to heat treatment to make them safe for human consumption and to extend their shelf life (Zanabria et al., 2014). However, heating can induce denaturation, aggregation, and even gelation of milk proteins (Wijayanti et al., 2014). Therefore, if MFGM proteins are going to be used as a source of nutraceutical compounds, the effect of heat treatments on them is of interest.

The hydrolysis of milk proteins with food-grade proteinases offers an efficient way to obtain products partially or extensively hydrolyzed for individuals with allergies (Bu et al., 2013). Furthermore, milk proteins are precursors of many biologically active peptides, which are released by proteolytic enzymes (Korhonen, 2009). Peptides derived from caseins and whey proteins have been extensively studied (Phelan et al., 2009; Madureira et al., 2010), whereas little is known about peptides from MFGM proteins.

The purpose of this study was to develop an ELISA for the quantification of lactadherin in raw (buttermilk and whey) and commercial (skim milk, buttermilk, and butter serum) dairy by-products. Furthermore, the concentration of immunoreactive lactadherin was estimated in raw products subjected to different heat treatments and in commercial products hydrolyzed using 3 enzymatic preparations.

\section{MATERIALS AND METHODS}

\section{Extraction of MFGM and Lactadherin- Enriched Fraction}

The MFGM fraction was obtained from raw bovine milk supplied by a local dairy industry (Villacorona, El Burgo de Ebro, Spain). Milk was heated at $50^{\circ} \mathrm{C}$ and separated into cream and skim milk using a cream separator (ARR-DES 125, Suministros Químicos Ar- royo, Santander, Spain). Cream was washed 3 times with Milli-Q water (Millipore, Billerica, MA) to remove caseins and whey proteins and centrifuged between each wash at $3,400 \times g$ for $15 \mathrm{~min}$ at $4^{\circ} \mathrm{C}$. Then, washed cream was churned to obtain butter and buttermilk. Butter was heated at $40^{\circ} \mathrm{C}$ for $15 \mathrm{~min}$ and centrifuged at $3,000 \times g$ for $15 \mathrm{~min}$, resulting in an upper phase (oil) and a lower phase (butter serum). Buttermilk and butter serum were mixed in a proportion of $7: 1$ ( $\mathrm{vol} /$ vol), filtered through glass wool, and acidified to $\mathrm{pH} 4.8$ with $1 \mathrm{M} \mathrm{HCl}$. The mixture was stirred for $30 \mathrm{~min}$ and centrifuged at $40,000 \times g$ for $30 \mathrm{~min}$ at $4^{\circ} \mathrm{C}$ to obtain the precipitated MFGM fraction. Afterward, this fraction was subjected to centrifugation at $25,000 \times g$ for 1 $\mathrm{h}$ at $4^{\circ} \mathrm{C}$, and the supernatant was considered the lactadherin-enriched fraction (EF). Total protein content of lactadherin-EF was determined by the bicinchoninic acid (BCA) protein assay kit (Pierce Biotechnology, Rockford, IL).

The MFGM fraction was analyzed by SDS-PAGE and bands corresponding to the molecular weight of lactadherin were cut from the gel and analyzed by matrix-assisted laser desorption/ionization time-of-flight (MALDI-TOF) MS at the Proteomic Platform of the Barcelona Scientific Park (Barcelona, Spain).

\section{Isolation of Lactadherin}

The first step to obtain lactadherin was delipidation of the MFGM fraction, as described by Kanno et al. (1975). In this procedure, 9 volumes of a mixture of chloroform:methanol $(2: 1, \mathrm{vol} / \mathrm{vol})$ was mixed with 1 volume of MFGM fraction suspended in distilled water and stirred overnight at $4^{\circ} \mathrm{C}$ to obtain an emulsion. The emulsion was broken by adding 1 volume of Milli-Q water (Millipore) and centrifuging at $3,400 \times g$ for 15 min at $4^{\circ} \mathrm{C}$. The material between the chloroform phase and the methanol-water phase was collected and the residual solvent was evaporated under vacuum. Finally, the delipidated MFGM fraction was freeze-dried.

The remainder of the procedure for the isolation of lactadherin was a modification of the method described by Kim et al. (1992). Briefly, the delipidated MFGM fraction was suspended in $0.2 \mathrm{M} \mathrm{NaCl}$ and centrifuged at $25,000 \times g$ for $1 \mathrm{~h}$ at $4^{\circ} \mathrm{C}$. The pellet was dispersed in $0.1 M$ Tris- $\mathrm{HCl}(\mathrm{pH} 8.2)$, containing $5 \mathrm{M}$ urea, 1 $M \mathrm{KCl}$, and $20 \mathrm{~m} M$ benzamidine, and centrifuged at $40,000 \times g$ for $30 \mathrm{~min}$ at $4^{\circ} \mathrm{C}$. The supernatant was concentrated using centrifugal filters with a $10-\mathrm{kDa}$ cut-off (Merck Millipore, Darmstadt, Germany) and subjected to gel filtration on a Sephacryl S-200 column (GE Healthcare, Uppsala, Sweden). Chromatographic fractions containing lactadherin were collected, concentrated, and dialyzed for $2 \mathrm{~d}$ against $10 \mathrm{mM}$ Tris- $\mathrm{HCl}$ 
(pH 7.2) with $0.15 M \mathrm{KCl}, 0.2 M \mathrm{NaCl}, 1 \mathrm{~m} M \mathrm{MnCl}_{2}$, and $1 \mathrm{mM} \mathrm{CaCl}$, with several changes. Afterward, this material was subjected to affinity chromatography on a Concanavalin A Sepharose 4B column (GE Healthcare). The lactadherin bound to the gel was eluted with

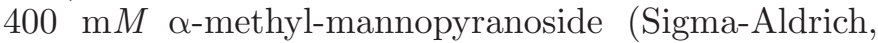
St Louis, MO). Fractions containing lactadherin were concentrated, dialyzed, and analyzed by electrophoresis and Western blotting.

\section{Preparation of Raw Buttermilk and Whey}

Cream obtained from raw bovine milk was churned as described above to produce butter and buttermilk. Then, the buttermilk was filtered through cheese cloth and glass wool to remove remaining butter granules.

Whey was obtained from skim milk by enzymatic coagulation. Recombinant chymosin (Chr. Hansen, Hørsholm, Denmark) was added to skim milk according to the manufacturer's recommendations. After coagulation for $45 \mathrm{~min}$ at $35^{\circ} \mathrm{C}$, whey was recovered by decanting the coagulum and filtering it through glass wool.

Buttermilk and whey were freeze-dried and stored at $-20^{\circ} \mathrm{C}$ until use. Protein contents of these products was determined by the BCA.

\section{Commercial Products}

Three commercial dairy by-products were used in this study: skim milk, butter serum, and buttermilk, all supplied as powders. According to manufacturer specifications, all were obtained from pasteurized bovine milk $\left(72^{\circ} \mathrm{C}\right.$ for $\left.15 \mathrm{~s}\right)$. Skim milk and butter serum are by-products derived from the process used to obtain anhydrous milk fat. Skim milk is obtained by centrifugation in the process of concentrating fat to $75 \%$. Butter serum is the liquid phase obtained after phase inversion of concentrated fat and subsequent melting and centrifugation. Buttermilk is released in the process of churning cream to prepare butter. The protein content of these products was determined by the BCA assay.

\section{Heat Treatment of Raw Buttermilk and Whey}

Heat treatments applied to raw buttermilk and whey were performed as described by Parrón et al. (2016). Briefly, aliquots of whey and buttermilk were placed in glass Erlenmeyer flasks and transferred to a thermostatic bath at the desired temperature $\left( \pm 0.1^{\circ} \mathrm{C}\right)$. The temperature inside the samples was monitored by using a digital thermometer. The treatments applied were $45^{\circ} \mathrm{C}$ for $60 \mathrm{~min} ; 55^{\circ} \mathrm{C}$ for $60 \mathrm{~min} ; 65^{\circ} \mathrm{C}$ for $60 \mathrm{~min} ; 72^{\circ} \mathrm{C}$ for $15 \mathrm{~s}, 1 \mathrm{~min}, 10 \mathrm{~min}$, or $60 \mathrm{~min} ; 75^{\circ} \mathrm{C}$ for $20 \mathrm{~s}$ or 10 min; $80^{\circ} \mathrm{C}$ for $20 \mathrm{~s}$ or $10 \mathrm{~min}$; and $85^{\circ} \mathrm{C}$ for $20 \mathrm{~s}$ or 10 min. After heat treatment, samples were immediately cooled by immersion in an ice-water bath and stored at $-20^{\circ} \mathrm{C}$ until freeze-drying.

\section{Hydrolysis of Commercial Products}

Hydrolysis of proteins from skim milk, buttermilk, and butter serum was carried out according to Ripollés et al. (2016). The enzymatic preparations used were Alcalase 2.4 L (Sigma-Aldrich), Prolyve 1000 (kindly supplied by Lyven Enzymes Industrielles, Caen, France), and Corolase PP (AB Enzymes, Darmstadt, Germany). Alcalase and Prolyve were added at $0.5 \%$ ( $\mathrm{vol} / \mathrm{vol}$ ) and Corolase PP at an enzyme:substrate ratio of $1 \%$ (wt/ wt). All hydrolysis treatments were carried out at a constant $\mathrm{pH}$ of 7.0 for $4 \mathrm{~h}$ using a $\mathrm{pH}$ Stat (842 Titrando, Metrohm, Herisau, Switzerland). The enzyme was inactivated by heating the hydrolysates at $90^{\circ} \mathrm{C}$ for 20 min. Hydrolysates were freeze-dried and stored at $-20^{\circ} \mathrm{C}$ until analysis.

\section{SDS-PAGE and Western Blotting}

The MFGM fraction, purified lactadherin, and heattreated samples were analyzed by SDS-PAGE according to the method of Laemmli (1970). Samples were mixed (1:1) with $126 \mathrm{~m} M$ Tris-HCl, $\mathrm{pH}$ 6.8, containing $20 \%$ glycerol, $4 \%$ SDS, and $0.02 \%$ bromophenol blue, and treated at $100^{\circ} \mathrm{C}$ for $5 \mathrm{~min}$. For electrophoresis under reducing conditions, buffer was supplemented with $10 \% \beta$-mercaptoethanol. Afterward, samples and molecular weight markers from Thermo Fisher Scientific (Waltham, MA) or GE Healthcare were applied to $4-20 \%$ or $10 \%$ (wt/vol) precast polyacrylamide gels. Electrophoresis was carried out using a Mini-Protean Tetra Cell (Bio-Rad Laboratories, Hercules, CA) at $180 \mathrm{~V}$ for $30 \mathrm{~min}$. Gels were stained with Coomassie blue or silver nitrate according to standard procedures. The presence of lactadherin in the purified fraction was confirmed by Western blotting, according to the procedure described by Benfeldt et al. (1995), using specific antibodies kindly donated by Jan Trige Rasmussen (Protein Chemistry Laboratory, University of Aarhus, Denmark).

\section{Obtaining Rabbit Antiserum Against Lactadherin}

The procedure used for obtaining rabbit antiserum against lactadherin was a modification of that described by Drenckhahn et al. (1993). Electrophoretic bands corresponding to lactadherin, as confirmed by MALDI-TOF MS, were cut from 10 lanes with a sterile scalpel. Then, the bands were homogenized and suspended in $0.5 \mathrm{~mL}$ of a phosphate buffer (PBS; $8.1 \mathrm{mM}$ 
$\mathrm{Na}_{2} \mathrm{HPO}_{4}, 1.4 \mathrm{~m} M \mathrm{KH}_{2} \mathrm{PO}_{4}, 0.14 \mathrm{~m} M \mathrm{NaCl}, 2.6 \mathrm{~m} M$ $\mathrm{KCl}, \mathrm{pH}$ 7.4), mixed with $0.5 \mathrm{~mL}$ of complete Freund's adjuvant (Sigma-Aldrich), and sonicated for $45 \mathrm{~s}$ to obtain an emulsion. This mixture was inoculated subcutaneously into rabbits. After $1 \mathrm{mo}$, the rabbits were inoculated again using incomplete Freund's adjuvant (Sigma-Aldrich). Ten days after the second immunization, rabbits were bled from the ear vein. Thereafter, rabbits were immunized and bled every 2 wk until 3 blood extractions were obtained. Blood was coagulated at room temperature and centrifuged at 1,000 $\times g$ for 10 min to obtain antiserum, which was kept at $-20^{\circ} \mathrm{C}$.

\section{Noncompetitive and Indirect Competitive ELISA}

Noncompetitive ELISA was used for the titration of rabbit antisera, as described below. First, the wells of the 96-well microtiter plates (Nunc A/S, Roskilde, Denmark) were coated with $120 \mu \mathrm{L}$ of lactadherin-EF at a concentration of $10 \mu \mathrm{g} / \mathrm{mL}$ in $50 \mathrm{mM} \mathrm{Na} \mathrm{CO}_{3}, \mathrm{pH}$ 9.6. After incubating overnight at $4^{\circ} \mathrm{C}$, the wells were washed 5 times with $300 \mu \mathrm{L}$ of distilled water, and the residual protein binding sites were blocked with 300 $\mu \mathrm{L} /$ well of $3 \%$ ovalbumin in PBS for $2 \mathrm{~h}$ at $37^{\circ} \mathrm{C}$. Then, the wells were washed with $300 \mu \mathrm{L}$ of distilled water, air-dried, and stored at $4^{\circ} \mathrm{C}$ until use. For the titration assay, wells were washed 3 times with PBS containing 0.05\% Tween-20 (PBS-T) and incubated with $100 \mu \mathrm{L}$ of serial dilutions of rabbit antisera at $37^{\circ} \mathrm{C}$ for $1 \mathrm{~h}$. Then, the wells were washed 5 times with PBS-T and incubated with $100 \mu \mathrm{L}$ of goat anti-rabbit IgG conjugated with peroxidase (Sigma-Aldrich) diluted 1:4,000 in PBS. After washing the wells 5 times with PBS-T, they were incubated with $100 \mu \mathrm{L}$ of $3,3^{\prime}, 5,5^{\prime}$ tetramethylbenzidine (TMB) substrate (ZEULAB, Zaragoza, Spain) at room temperature for $20 \mathrm{~min}$. The enzymatic reaction was stopped by adding $50 \mu \mathrm{L}$ per well of $2 M$ $\mathrm{H}_{2} \mathrm{SO}_{4}$, and absorbance was measured at $450 \mathrm{~nm}$ using a microplate reader (Multiskan MS, Labsystem Helsinki, Finland). This titration allowed us to determine the optimal dilution of the antiserum for the competitive ELISA.

Indirect competitive ELISA was used to determine the concentration of lactadherin in dairy by-products before and after being subjected to heat and hydrolysis treatments. To perform the assay, the wells were coated as described above. After washing the wells 3 times with PBS-T, a volume of $50 \mu \mathrm{L}$ of standard or sample was added to wells, together with $50 \mu \mathrm{L}$ of the antiserum from the third extraction diluted 1:400 in PBS, incubating the plate at $37^{\circ} \mathrm{C}$ for $1 \mathrm{~h}$. The lactadherin$\mathrm{EF}$ at protein concentrations between 5 and $250 \mu \mathrm{g} / \mathrm{mL}$ was used as standard. After this incubation, the wells were washed 5 times with PBS-T and the procedure followed as described for the titration assay (noncompetitive ELISA).

\section{Statistical Analysis}

Data were analyzed for statistical significance using IBM SPSS software 22.0 (IBM Corp., Armonk, NY). Levene's test was applied to check homoscedasticity of the data, and the Shapiro-Wilk test was applied to check Gaussian distribution before data analysis by one-way ANOVA. The Games-Howell post hoc test was used to assess differences between mean values. Data were considered significantly different when $P<0.05$.

\section{RESULTS}

\section{Obtaining Rabbit Antisera Against Lactadherin and Titration}

The isolated MFGM fraction was characterized by electrophoresis (Figure 1). The 2 major bands, A and $\mathrm{B}$, with a molecular weight between 40 and $55 \mathrm{kDa}$ were cut from the gel and analyzed by MALDI-TOF MS. Bands A and B had sequence coverage of 75.41 and $75.88 \%$ for PAS- 6 and PAS-7, respectively. These 2 bands were used to immunize rabbits to raise specific antisera, which were used to develop the indirect competitive ELISA for the determination of lactadherin concentration.

The titer of an antiserum is defined as the inverse of the dilution that yields half of the maximum absorbance $\left(\mathrm{A}_{450 \mathrm{~nm}}\right)$ in an indirect noncompetitive ELISA (Switzer and Garrity, 1999). In our study, the titer of antisera increased with subsequent extractions, being about 181, 256, and 512 for the first, second, and third extractions, respectively (Figure 2).

\section{Determination of Lactadherin Concentration in Enriched Fraction}

Purified lactadherin was characterized by SDS-PAGE (Figure 3a) and Western blotting using specific antibodies (Figure 3b). A calibration curve was obtained for the indirect competitive ELISA (Figure 4a), using the relationship between the values of absorbance and the logarithm of the concentration of lactadherin standards dissolved in PBS, which was linear within a range from 4 to $206 \mathrm{mg} / \mathrm{mL}\left(\mathrm{R}^{2}>0.96\right)$. Then, the lactadherin concentration in the $\mathrm{EF}$ was determined by interpolation of its absorbance values in the calibration curve obtained with the purified protein. 


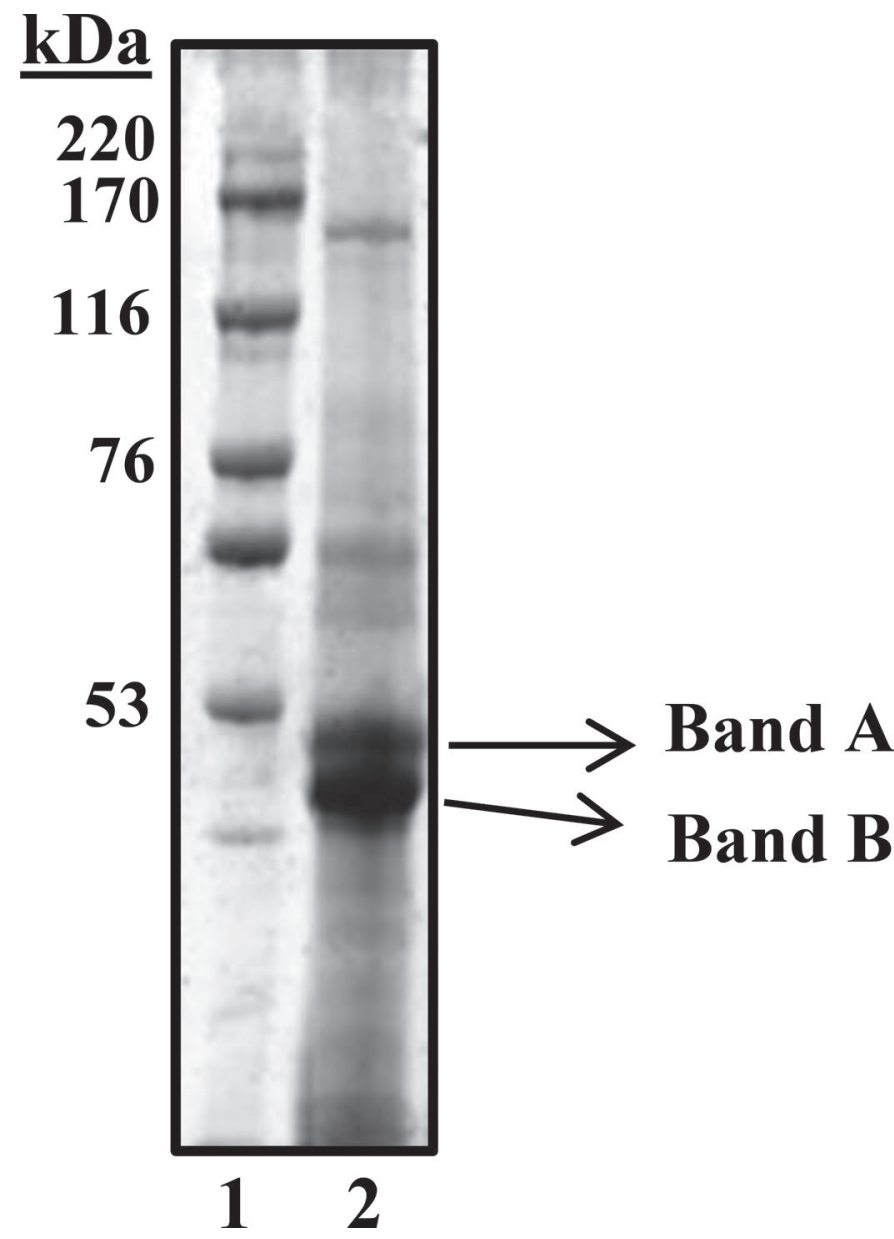

Figure 1. Sodium dodecyl sulfate-PAGE of the milk fat globule membrane (MFGM) fraction isolated from raw bovine milk. Lane $1=$ molecular mass marker $(220,170,116,76,53 \mathrm{kDa})$; lane $2=\mathrm{MFGM}$ fraction. Bands identified as $\mathrm{A}$ and $\mathrm{B}$, corresponding to lactadherin glycosylation variants according to their molecular mass, were removed and analyzed by matrix-assisted laser desorption/ionizationtime of flight (MALDI-TOF) MS. Electrophoresis was performed under reducing conditions in 10\% polyacrylamide gel that was stained with Coomassie blue.

The concentration of lactadherin in the EF was $43 \%$ of total protein content. This EF was used to prepare standards for the indirect competitive ELISA, obtaining calibration curves such as that shown in Figure 4b. Thus, a correction factor of 0.43 was applied to calculate the actual concentration of lactadherin in the dairy samples analyzed.

\section{Concentration of Lactadherin in Dairy By-Products}

Total protein concentration, determined by BCA assay, was similar among all dairy by-products except for whey, which had the lowest content (Table 1). The concentration of lactadherin in the commercial dairy by-products differed depending on their origin, rang- ing between 4.84 and $5.27 \mathrm{mg} / \mathrm{g}$ of product; buttermilk had the highest content. Raw buttermilk contained a greater amount of lactadherin $(6.79 \mathrm{mg} / \mathrm{g})$ than commercial products and the proportion of lactadherin to total protein content was also higher. The concentration of lactadherin was lower in whey than in other products $(1.20 \mathrm{mg} / \mathrm{g})$.

\section{Effect of Heat Treatment on the Immunoreactivity of Lactadherin}

Raw whey and buttermilk subjected to heat treatments of differing intensity were analyzed by SDSPAGE under nonreducing conditions. The bands corresponding to the glycosylation variants of lactadherin, PAS-6 and PAS-7, were less intense in raw whey (Figure 5a) than in raw buttermilk (Figure 5b), which is in agreement with the lower content of lactadherin found in raw whey. Heat treatment of buttermilk resulted in a decrease in the intensity of lactadherin bands, which were not visible after treatment at $75^{\circ} \mathrm{C}$ for $20 \mathrm{~s}$. In the case of heated whey, it was difficult to discern changes in lactadherin bands because they were faint and diffuse.

The effect of heat treatment on lactadherin concentration, determined by ELISA, is shown in Figure 6 . In both whey and buttermilk, the concentration of immunoreactive lactadherin decreased with the intensity of heat treatment. The differences compared with the untreated product were statistically significant in some cases $(P<0.05)$.

The effect of heat treatment on lactadherin concentration differed depending on the dairy by-product. Heat

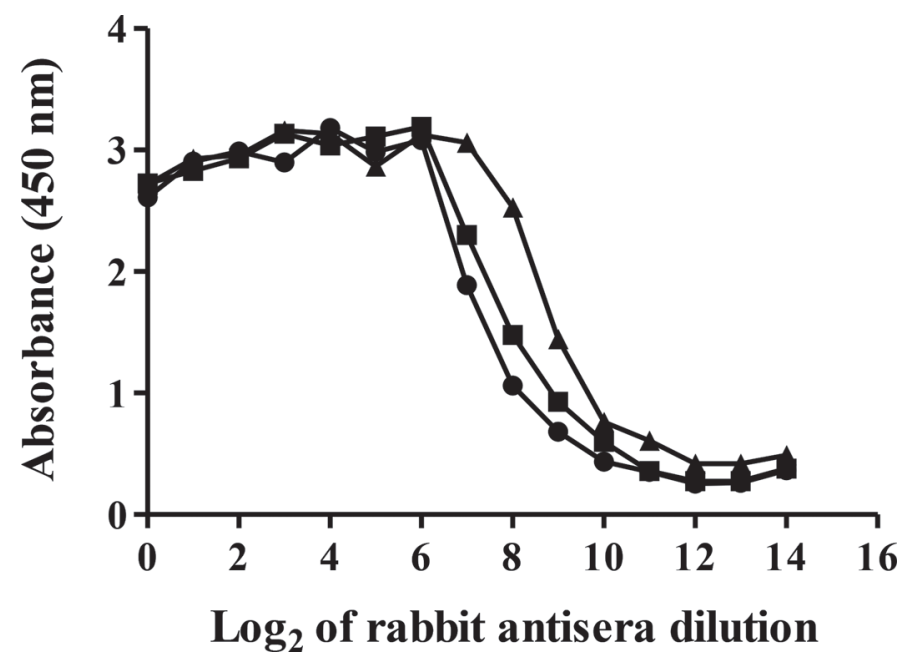

Figure 2. Titration of rabbit antisera against lactadherin obtained from the first $(\boldsymbol{\bullet})$, second $(\boldsymbol{\square})$, and third $(\boldsymbol{\Lambda})$ extractions through noncompetitive ELISA. 
$\underline{\text { kDa }}$ (a)

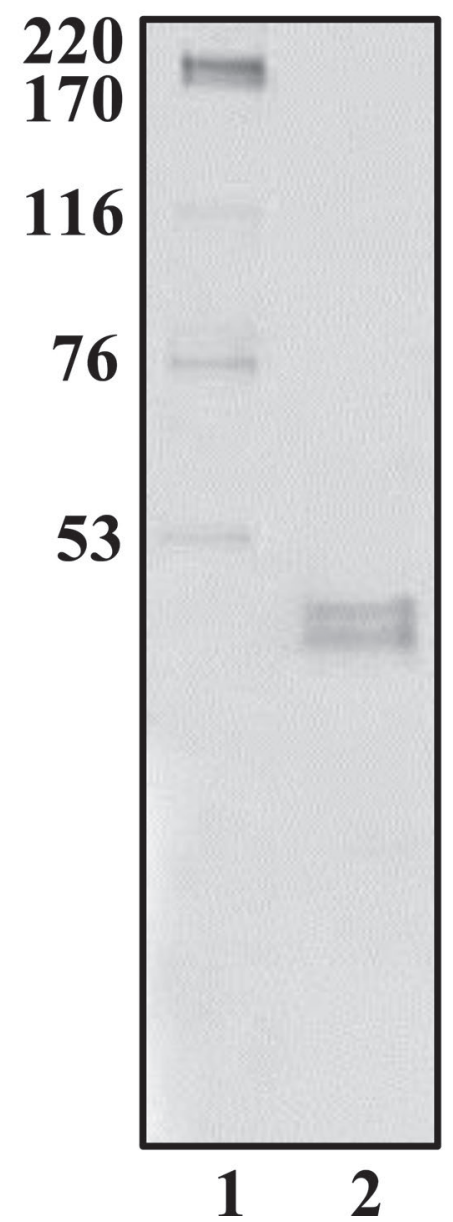

Figure 3. Sodium dodecyl sulfate-PAGE (a) and Western blotting (b) of purified bovine lactadherin. Lane $1=$ molecular mass marker $(220,170,116,76,53 \mathrm{kDa})$; lane $2=$ pure lactadherin. Electrophoresis was performed under reducing conditions in 4 to $20 \%$ polyacrylamide gel that was stained with silver nitrate. Western blotting was done by using specific antibodies against lactadherin. (a)

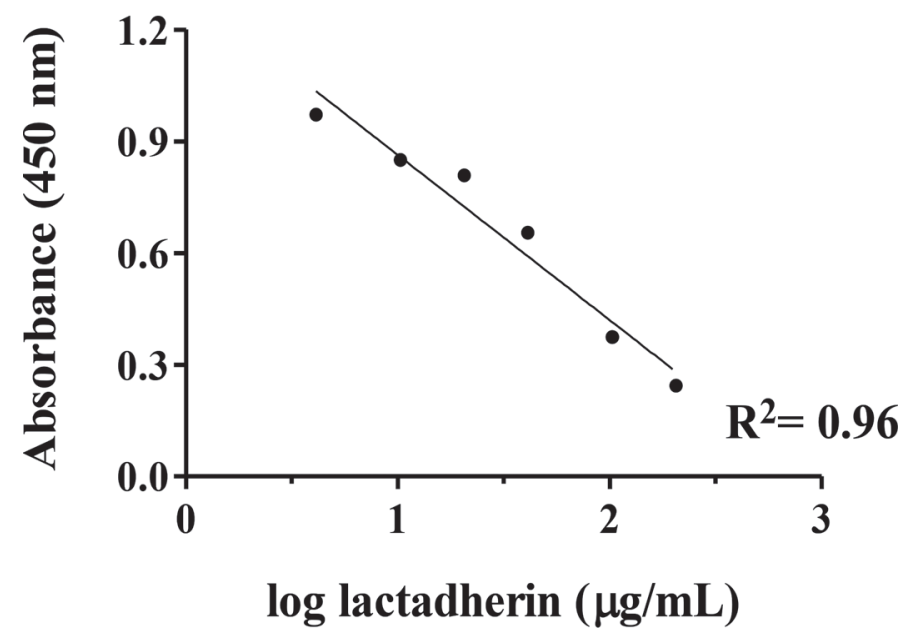

(b)

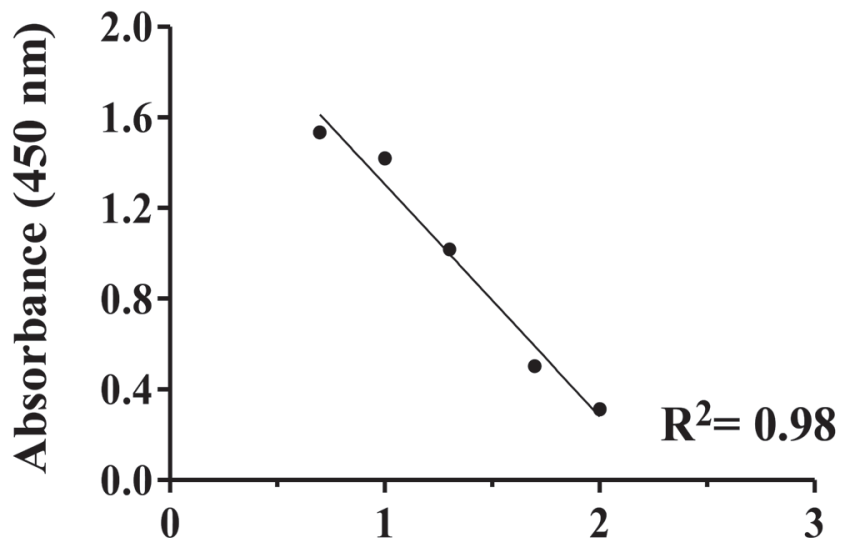

$\log$ total protein $(\mu \mathrm{g} / \mathrm{mL})$

Figure 4. Calibration curve obtained for pure bovine lactadherin (a) and for lactadherin-enriched fraction (b) by an indirect competitive ELISA. Values represent the mean of at least 9 replicates from 3 independent experiments.

Table 1. Concentration of total protein and lactadherin in dairy by-products, determined by bicinchoninic acid assay and indirect competitive ELISA, respectively ${ }^{1}$

\begin{tabular}{lccc}
\hline Dairy by-product & $\begin{array}{c}\text { Total protein content } \\
\text { (mg/g of product) }\end{array}$ & $\begin{array}{c}\text { Lactadherin } \\
\text { concentration } \\
(\mathrm{mg} / \mathrm{g} \text { of product })\end{array}$ & $\begin{array}{c}\text { Lactadherin/total } \\
\text { protein }(\%)\end{array}$ \\
\hline Commercial skim milk & $301.03 \pm 15.81$ & $4.84 \pm 0.38$ & 1.61 \\
Commercial butter serum & $247.77 \pm 11.36$ & $4.86 \pm 0.36$ & 1.96 \\
Commercial buttermilk & $286.63 \pm 26.84$ & $5.27 \pm 0.24$ & 1.84 \\
Raw buttermilk & $225.63 \pm 26.84$ & $6.79 \pm 0.26$ & 3.01 \\
Raw whey & $127.88 \pm 6.19$ & $1.20 \pm 0.20$ & 0.94 \\
\hline
\end{tabular}

${ }^{1}$ Values represent the mean $\pm \mathrm{SD}$ of at least 9 replicates from 3 independent experiments. 
(a)

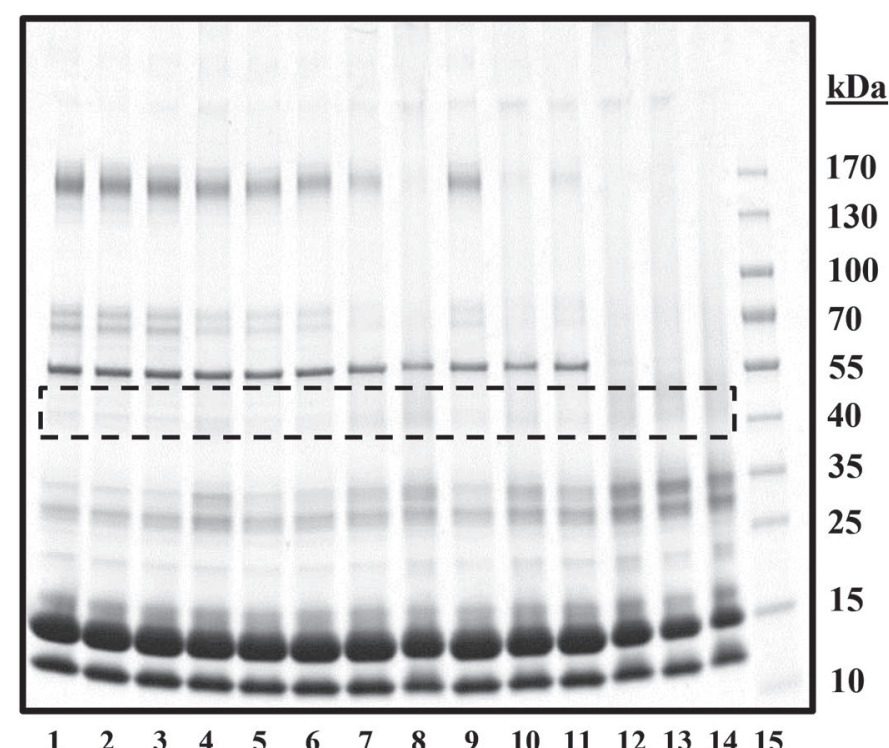

(b)

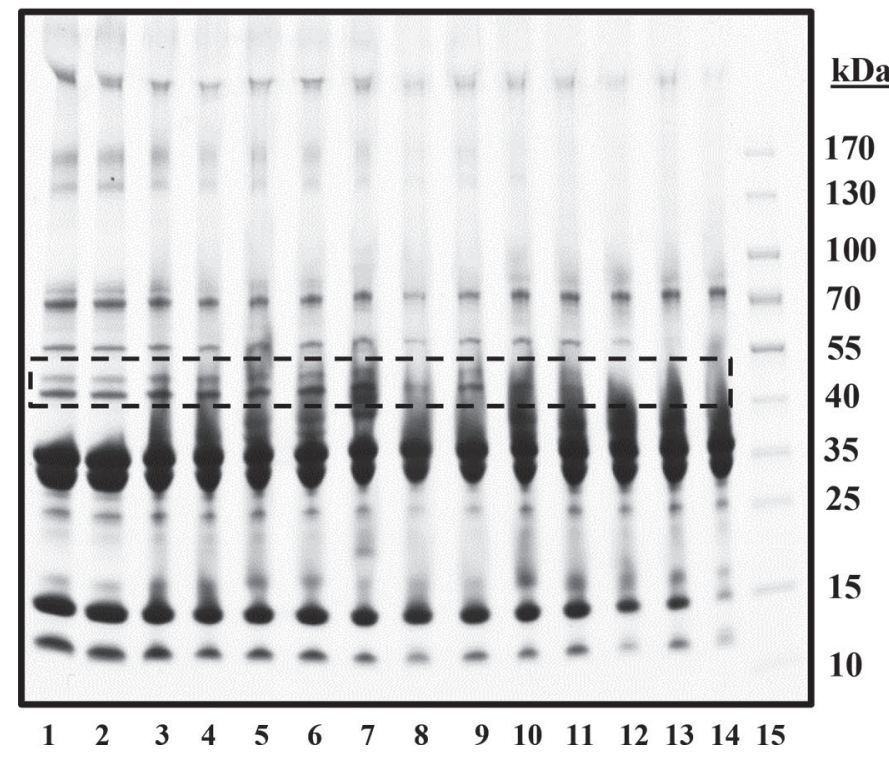

Figure 5. Sodium dodecyl sulfate-PAGE of heat-treated bovine whey (a) and buttermilk (b). Lane $1=$ untreated product; lane $2=$ treated at $45^{\circ} \mathrm{C}$ for $60 \mathrm{~min}$; lane $3=55^{\circ} \mathrm{C}$ for $60 \mathrm{~min}$; lane $4=65^{\circ} \mathrm{C}$ for $60 \mathrm{~min}$; lane $5=72^{\circ} \mathrm{C}$ for $15 \mathrm{~s}$; lane $6=72^{\circ} \mathrm{C}$ for $1 \mathrm{~min}$; lane $7=$ $72^{\circ} \mathrm{C}$ for $10 \mathrm{~min}$; lane $8=72^{\circ} \mathrm{C}$ for $60 \mathrm{~min}$; lane $9=75^{\circ} \mathrm{C}$ for $20 \mathrm{~s}$; lane $10=75^{\circ} \mathrm{C}$ for $10 \mathrm{~min}$; lane $11=80^{\circ} \mathrm{C}$ for $20 \mathrm{~s}$; lane $12=80^{\circ} \mathrm{C}$ for 10 $\min$; lane $13=85^{\circ} \mathrm{C}$ for $20 \mathrm{~s}$; lane $14=85^{\circ} \mathrm{C}$ for $10 \mathrm{~min}$; lane $15=$ molecular mass marker $(170,130,100,70,55,40,35,25,15,10 \mathrm{kDa})$. Electrophoresis was performed under nonreducing conditions in 4 to $20 \%$ polyacrylamide gel that was stained with Coomassie blue. The dotted box area in the 2 electrophoreses indicates lactadherin bands.

treatments resulted in a greater decrease of lactadherin in whey than in buttermilk when both products were treated at $72^{\circ} \mathrm{C}$ for $10 \mathrm{~min}$ or higher intensity, except for the treatment at $75^{\circ} \mathrm{C}$ for $20 \mathrm{~s}$. Heat treatments of whey at $72^{\circ} \mathrm{C}$ for $60 \mathrm{~min}$ and buttermilk at $85^{\circ} \mathrm{C}$ for 10 min resulted in the greatest decreases in lactadherin concentration. After these treatments, the percentage of lactadherin remaining was about $52 \%$ in whey and $72 \%$ in buttermilk.

\section{Effect of Hydrolysis on the Immunoreactivity of Lactadherin}

The effect of incubation with enzyme preparations (Alcalase, Prolyve, and Corolase PP) on the concentration of immunoreactive lactadherin in commercial products is shown in Figure 7. For all enzymatic preparations and products assayed, the concentration of lactadherin decreased markedly, by more than $80 \%$ of the initial value, within the first 5 min of treatment. Thereafter, lactadherin decreased slowly and a residual immunoreactivity of 10 to $20 \%$ remained after $4 \mathrm{~h}$ of incubation. Alcalase caused the greatest reduction of lactadherin concentration after $4 \mathrm{~h}$ of hydrolysis in skim milk and buttermilk, and Corolase PP caused the greatest reduction of lactadherin in butter serum. For all incubation times and all enzyme preparations, the differences were statistically significant $(P<0.001)$ compared with the nonhydrolyzed product.

\section{DISCUSSION}

The proteins present in the MFGM account for 1 to $2 \%$ of total protein content in bovine milk and they are present in different locations within the membrane (Dewettinck et al., 2008). The major bovine MFGM proteins are butyrophilin, adipophilin, xanthine oxidoreductase, and lactadherin (Affolter et al., 2010). Our study focused on lactadherin, a protein loosely attached to the MFGM that is also expressed in other tissues and for which several biological functions have been proposed (Rasmussen, 2009).

The concentration of lactadherin in dairy by-products was calculated by an indirect competitive ELISA developed in the present study. The concentration of lactadherin in products derived from the processing of milk fat, buttermilk, butter serum, and skim milk was higher than that in whey, which can be explained by the higher content of MFGM fragments in those fractions. Several authors have indicated that buttermilk and butter serum are enriched in components derived from the MFGM (Rombaut et al., 2006; Vanderghem et al., 2010). To date, few studies have been performed to estimate the concentration of MFGM proteins in dairy by-products, probably because of their hydrophobic nature and association with the fat globule membrane. Fong and Norris (2009) determined the concentration 
of 6 MFGM proteins in 2 buttermilk protein concentrates containing 50 to $60 \%$ protein, by using the absolute quantification technique. This technique is based on the measurement of cleavage peptide sequences by liquid chromatography-high resolution selected reaction monitoring mass spectrometry. Fong and Norris (2009) found that the concentration of lactadherin in buttermilk concentrates varied between 20 and 56 $\mathrm{mg} / \mathrm{g}$ of product, depending on the peptide sequence. These values are much higher than those obtained in our study, presumably because of the different technique used for quantification and the protein contents of the dairy products analyzed.

Recently, Holzmüller and Kulozik (2016) calculated the concentrations of lactadherin, butyrophilin, and xanthine oxidoreductase in buttermilk and butter serum obtained from raw bovine milk. The technique used in that study was based on the relationship between the fluorescence intensity of protein bands separated by electrophoresis and their tryptophan content. Those authors reported a lactadherin concentration of 0.85 $\mathrm{g} / \mathrm{L}$ in buttermilk, which represents around $2.5 \%$ of the total protein content in that product. This percentage is similar to that obtained in our study, in which lactadherin accounted for $3 \%$ of total protein in raw buttermilk. Furthermore, Holzmüller and Kulozik (2016) reported that the amount of lactadherin as a percentage of total protein was higher in butter serum than in buttermilk. This fact is in agreement with our results and can be explained by the comparatively higher level of MFGM components in butter serum than in buttermilk.

The intensity of electrophoretic bands corresponding to lactadherin in raw buttermilk and whey decreased with heat treatment, although is difficult to estimate the true concentration because bands were not well defined. The effect of heat treatment on lactadherin has been analyzed by electrophoresis previously. Houlihan et al. (1992a) reported a large decrease in the intensity of lactadherin bands (PAS-6 and PAS-7) in a MFGM fraction obtained from whole milk treated at $80^{\circ} \mathrm{C}$ for 20 min. Likewise, Ye et al. (2002) observed a clear decrease in the intensity of electrophoretic bands corresponding to lactadherin in the MFGM fraction isolated from washed cream heated at $80^{\circ} \mathrm{C}$ for $10 \mathrm{~min}$. Furthermore, Ye et al. (2002) noted that treatment at $70^{\circ} \mathrm{C}$ for 40 min did not result in a great decrease in lactadherin band intensity in washed cream, as determined by SDS-PAGE under nonreducing conditions. In contrast, Lee and Sherbon (2002) analyzed MFGM fractions extracted from raw milk and from milk treated at $80^{\circ} \mathrm{C}$ for 3 to $18 \mathrm{~min}$ by SDS-PAGE and found that the band corresponding to PAS-6 disappeared after treatment, whereas the band corresponding to PAS-7 was weakly stained regardless of the duration of heat treatment. The results obtained by Lee and Sherbon (2002) are in conflict with those obtained by Ye et al. (2004), who reported that the PAS-7 band of a MFGM fraction obtained from whole milk treated for 10 min at $>75^{\circ} \mathrm{C}$ or at $70^{\circ} \mathrm{C}$ for $>20$ min almost disappeared in electropho-

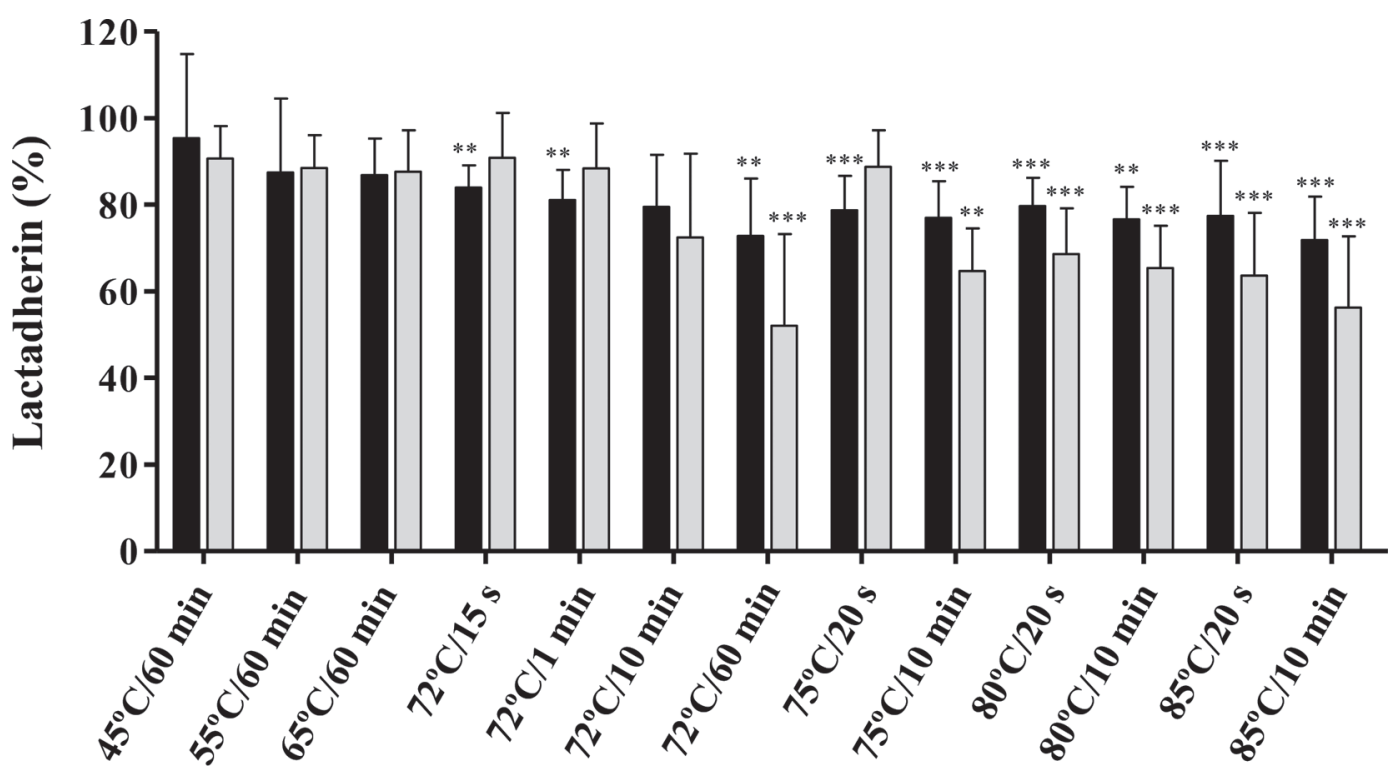

Figure 6. Effect of heat treatment on lactadherin concentration in buttermilk (black bars) and whey (gray bars), determined by indirect competitive ELISA. Values represent the mean \pm SD of at least 9 replicates from 3 independent experiments. Asterisks indicate a statistical difference with respect to the untreated corresponding product. 
resis gels, whereas PAS-6 decreased only slightly with increasing heat treatment intensity. In some studies, the MFGM fraction was isolated after heat treatment

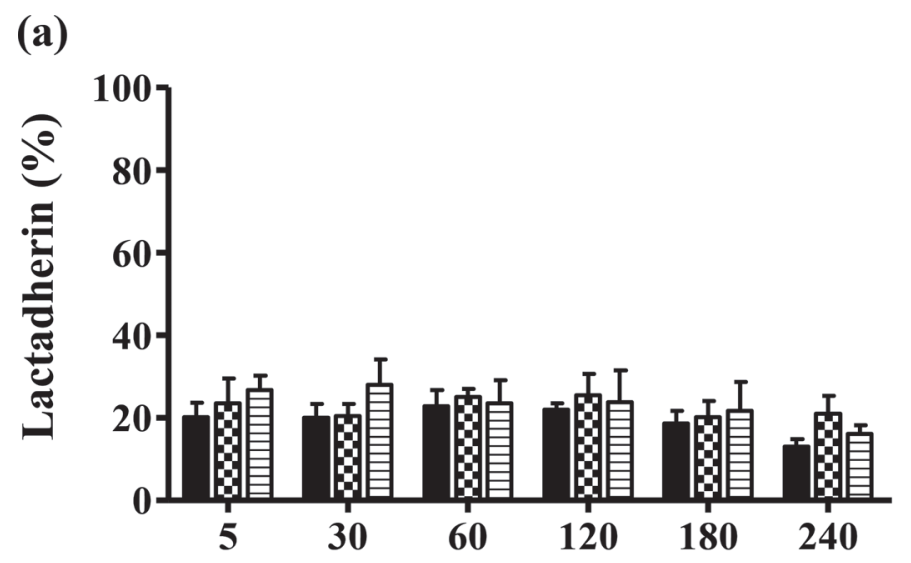

(b)

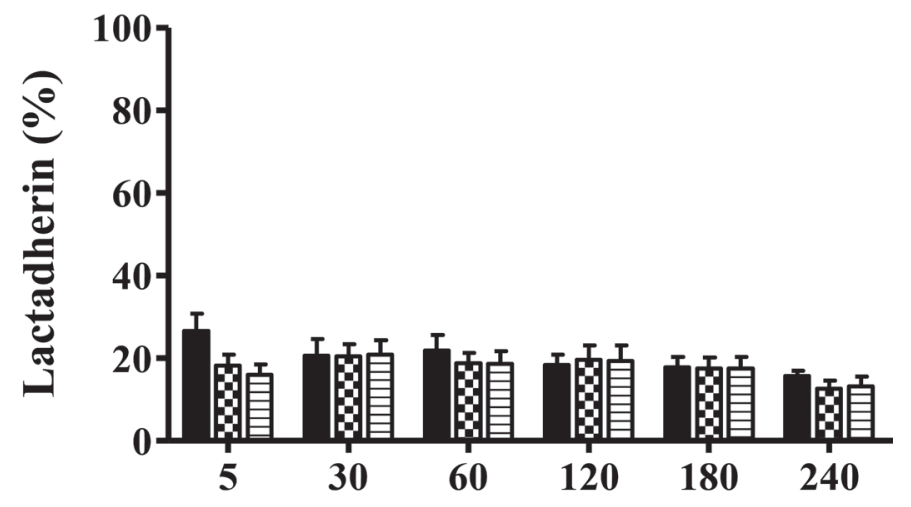

(c)

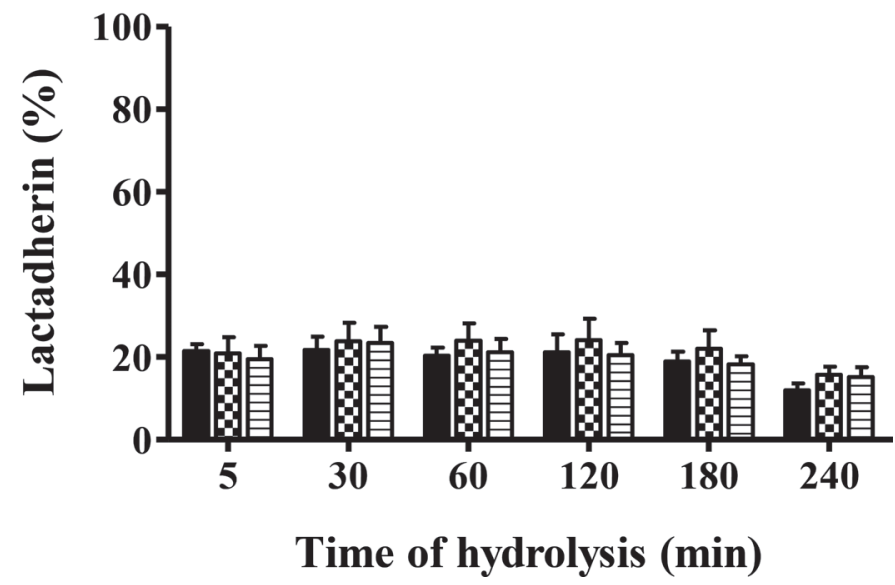

Figure 7. Effect of hydrolysis on the concentration of lactadherin in commercial skim milk (a), butter serum (b) and buttermilk (c), determined by indirect competitive ELISA. The enzymatic preparations used were Alcalase (black bars; Sigma-Aldrich Co., St. Louis, MO), Corolase PP (checked bars; AB Enzymes, Darmstadt, Germany), and Prolyve (striped bars; Lyven Enzymes Industrielles, Caen, France). Values represent the mean $\pm \mathrm{SD}$ of at least 6 replicates from 3 independent experiments. of milk or cream and, because lactadherin could have been displaced from skim milk components to the serum phase, the actual content of this protein could have been underestimated (Houlihan et al., 1992b; Ye et al., 2004). Furthermore, these results should be carefully considered because of the different staining behavior of proteins (Holzmüller and Kulozik, 2016).

In the last decades, ELISA has been extensively used to measure proteins in milk and determine their loss of immunoreactivity after applying technological treatments (Jeanson et al., 1999; Mayayo et al., 2014). We consider that results obtained by ELISA using specific antisera against the target protein are more accurate and reliable for determining the extent of denaturation than electrophoresis and measurement of electrophoretic band intensity. Besides electrophoresis, other methods have been used for determining milk proteins, such as HPLC. Although ultra-HPLC (UHPLC) coupled with tandem MS (MS/MS) is a very accurate technique and could be an alternative to immunochemical techniques, such as ELISA, there are many advantages of the latter versus the former: ELISA is a high-throughput method and the sample does not need any special preparation. Moreover, the equipment used for UHPLC-MS/MS, together with the internal standards and reagents, make the technique much more expensive than ELISA. In contrast, ELISA can be performed in most laboratories, because only a microplate reader and basic laboratory materials are required. Because it is essential to analyze lactadherin in commercial heat-treated samples, partially denatured or aggregated proteins could be lost in the sample preparation (including filtration) required for UHPLC; therefore, the obtained concentration values might be lower than actual concentrations. Although some of the conformational epitopes can be lost during processing treatments, linear epitopes usually resist those treatments and react with antibodies, making it possible to estimate the degree of denaturation (de Luis et al., 2007). Finally, UHPLC-MS/MS requires prior enzymatic digestion for sample preparation and, because this treatment is not very repeatable, it should be considered a technique for confirmation rather than for screening or quantification of the proteins (Baumgartner, 2010).

By means of competitive ELISA, we found that the concentration of lactadherin in whey and buttermilk subjected to heat treatment decreased with increasing temperature and duration of treatment to levels $50 \%$ of those in the untreated product. These results indicate that lactadherin is relatively stable to heat treatment. It is possible that the remaining immunoreactivity of lactadherin after heating dairy products would be due to linear epitopes that are not denatured, as has been 
shown for other milk proteins (Wehbi et al., 2005; de Luis et al., 2007).

Recently, Zhang et al. (2016) reported that pasteurization of bovine milk at $62^{\circ} \mathrm{C}$ for 30 min resulted in a decrease in lactadherin content of around $25 \%$ by using liquid chromatography-MS/MS. This decrease is greater than that obtained in our study after heating raw buttermilk (13.2\% decrease) and whey (12.4\% decrease) at $65^{\circ} \mathrm{C}$ for $60 \mathrm{~min}$, a similar temperature-time combination.

Taking into consideration that dairy products are often subjected to enzymatic hydrolysis to reduce their allergenicity (Bu et al., 2013), we studied the effect of treatment with food-grade proteinases on lactadherin content in commercial dairy products. The hydrolysates obtained with Alcalase, Corolase, and Prolyve of the same commercial products used in the present study were analyzed by electrophoresis in a previous study (Ripollés et al., 2016) in which antioxidant properties of hydrolysates were evaluated. The electrophoretic profiles showed that the 3 enzymes hydrolyzed almost all proteins in the first $5 \mathrm{~min}$ of incubation. The results of that study are in accordance with those obtained in the present work, because after 5 min of hydrolysis, immunoreactive lactadherin decreased by around $80 \%$ in all products, with the concentration remaining constant thereafter throughout $4 \mathrm{~h}$ of treatment. The high extent of hydrolysis obtained with commercial preparations in the present study is in accordance with the results obtained by Ye et al. (2011), who reported that the 2 glycosylation variants of lactadherin were almost completely hydrolyzed after treatment of raw milk with pepsin at $1.6 \mathrm{mg} / \mathrm{mL}$ for $30 \mathrm{~min}$. However, other authors have reported that human and bovine lactadherin are partly resistant to gastric conditions and pepsin activity (Peterson et al., 1998; Le et al., 2012) and to other enzymes such as trypsin or pronase E (Vanderghem et al., 2011). The resistance of bovine lactadherin to gastric conditions has been attributed to the protective effect of the lipids contained in the MFGM, because the peptic resistant moiety was hydrolyzed with pancreatin-containing lipases and phospholipases (Le et al., 2012). Despite the high content of lipids in the commercial products used in this study, lactadherin was hydrolyzed rapidly, probably due to the different cleavage sites of the enzymes used. These enzymes seem to break the immunoreactive linear epitopes of lactadherin that are not affected by heat treatment. Previous authors have reported substantial loss of immunoreactivity of milk proteins subjected to hydrolysis (Wróblewska and Troszyńska, 2005; Do et al., 2016). The loss of lactadherin observed in this study after hydrolysis of dairy by-products with Alcalase, Prolyve, and Corolase PP suggests that many peptides would have been released from the native protein. These peptides may exert many functions as other peptides from milk proteins do, such as lactoferricin and lactoferrampin released from lactoferrin, $\beta$-lactotensin from $\beta$-lactoglobulin, or $\alpha$-lactorphin from $\alpha$-lactalbumin (Madureira et al., 2010). Further research is needed to determine whether the peptides derived from lactadherin possess biological activities.

\section{CONCLUSIONS}

Dairy by-products from milk fat processing (skim milk, butter serum, and buttermilk) and, to a lesser extent, whey constitute an excellent source for isolating lactadherin with the aim of adding it to functional products. Raw buttermilk had the highest concentration of lactadherin $(6.79 \mathrm{mg} / \mathrm{g})$ of the by-products tested. Heat treatment of dairy products is an efficient way to ensure safety during shelf life while maintaining a certain level of lactadherin. However, further experiments are required to check whether the potential bioactivity of lactadherin is preserved after such treatments. Hydrolysis with food-grade proteinases produced a marked decrease of lactadherin concentration, much greater than that resulting from heat treatment. Peptides released from lactadherin by the action of proteolytic enzymes could have nutritional, functional, or biological activities, constituting a new challenge for dairy research.

\section{ACKNOWLEDGMENTS}

Daniel Ripollés López is grateful to the Aragón Government for a predoctoral grant. Financial support for this study was a Comisión Interministerial de Ciencia y Tecnología (Madrid, España) project (AGL2010-20835) and the European Social Fund. The authors declare that they have no competing interest.

\section{REFERENCES}

Affolter, M., L. Grass, F. Vanrobaeys, B. Casado, and M. Kussmann. 2010. Qualitative and quantitative profiling of the bovine milk fat globule membrane proteome. J. Proteomics 73:1079-1088. https:// doi.org/10.1016/j.jprot.2009.11.008.

Andersen, M. H., L. Berglund, J. T. Rasmussen, and T. E. Petersen. 1997. Bovine PAS-6/ 7 binds $\alpha_{\mathrm{V}} \beta_{5}$ integrin and anionic phospholipids through two domains. Biochemistry 36:5441-5446. https:// doi.org/10.1021/bi963119m.

Baumgartner, S. 2010. Milk allergen detection. Pages 349-357 in Molecular Biological and Immunological Techniques and Applications for Food Chemists. B. Popping, C. Díaz-Amigo and K. Hoenicke, ed. John Wiley \& Sons, Hoboken, NJ.

Benfeldt, C., L. B. Larsen, J. T. Rasmussen, P. A. Andreasen, and T. E. Petersen. 1995. Isolation and characterization of plasminogen and plasmin from bovine milk. Int. Dairy J. 5:577-592. https://doi .org/10.1016/0958-6946(94)00035-N. 
Bu, G., Y. Luo, F. Chen, K. Liu, and T. Zhu. 2013. Milk processing as a tool to reduce cow's milk allergenicity: A mini-review. Dairy Sci. Technol. 93:211-223. https://doi.org/10.1007/s13594-013-0113-x.

Butler, J. E., D. J. Pringnitz, C. L. Martens, and N. Crouch. 1980. Bovine-associated mucoprotein: I. Distribution among adult and fetal bovine tissues and body fluids. Differentiation 17:31-40. https:// doi.org/10.1111/j.1432-0436.1980.tb01079.x.

Conesa, C., M. Lavilla, L. Sánchez, M. D. Pérez, L. Mata, P. Razquín and M. Calvo. 2005. Determination of IgG levels in bovine bulk milk samples from different regions of Spain. Eur. Food Res. Technol. 220:222-225. https://doi.org/10.1007/s00217-004-1016-0.

Danthine, S., C. Blecker, M. Paquot, N. Innocente, and C. Deroanne. 2000. Évolution des connaissances sur la membrane du globule gras du lait: Synthèse bibliographique. Lait 80:209-222. https:// doi.org/10.1051/lait:2000120.

de Luis, R., M. D. Pérez, L. Sánchez, M. Lavilla, and M. Calvo. 2007. Development of two immunoassay formats to detect $\beta$-lactoglobulin: Influence of heat treatment on $\beta$-lactoglobulin immunoreactivity and assay applicability in processed food. J. Food Prot. 70:16911697. https://doi.org/10.4315/0362-028X-70.7.1691.

Dewettinck, K., R. Rombaut, N. Thienpont, T. Trung, K. Messens, and J. Van Camp. 2008. Nutritional and technological aspects of milk fat globule membrane material. Int. Dairy J. 18:436-457. https://doi.org/10.1016/j.idairyj.2007.10.014.

Do, A. B., K. Williams, and O. T. Toomer. 2016. In vitro digestibility and immunoreactivity of bovine milk proteins. Food Chem. 190:581-587. https://doi.org/10.1016/j.foodchem.2015.05.113.

Drenckhahn, D., T. Jöns, and F. Schmitz. 1993. Production of polyclonal antibodies against proteins and peptides. Methods Cell Biol. 37:7-56. https://doi.org/10.1016/S0091-679X(08)60242-3.

Dupont, D., C. Arnould, O. Rolet-Repecaud, G. Duboz, F. Faurie, B Martin, and E. Beuvier. 2006. Determination of bovine lactoferrin concentrations in cheese with specific monoclonal antibodies. Int. Dairy J. 16:1081-1087. https://doi.org/10.1016/j.idairyj.2005 .09 .012

Fong, B. Y., and C. S. Norris. 2009. Quantification of milk fat globule membrane proteins using selected reaction monitoring mass spectrometry. J. Agric. Food Chem. 57:6021-6028. https://doi.org/10 $.1021 / \mathrm{jf} 900511 \mathrm{t}$

Fong, B. Y., C. S. Norris, and A. K. H. MacGibbon. 2007. Protein and lipid composition of bovine milk-fat-globule membrane. Int. Dairy J. 17:275-288. https://doi.org/10.1016/j.idairyj.2006.05.004.

Haddadian, Z., G. T. Eyres, A. Carne, D. W. Everett, and P. Bremer 2017. Impact of different milk fat globule membrane preparations on protein composition, xanthine oxidase activity, and redox potential. Int. Dairy J. 64:14-21. https://doi.org/10.1016/j.idairyj 2016.09.006

He, S., Y. Ma, J. Wang, Q. Li, S. Tang, C. Zhao, H. Li, and J. L. Maubois. 2010. Characterization of fat globules and milk fat globule membrane proteins in milk of different yak breeds. Dairy Sci. Technol. 90:601-609. https://doi.org/10.1051/dst/2010022.

Holzmüller, W., and U. Kulozik. 2016. Quantification of MFGM proteins in buttermilk and butter serum by means of a stain free SDS-PAGE method. J. Food Compos. Anal. 49:102-109. https:// doi.org/10.1016/j.jfca.2016.04.003.

Houlihan, A. V., P. A. Goddard, B. J. Kitchen, and C. J. Masters. 1992a. Changes in structure of the bovine milk fat globule membrane on heating whole milk. J. Dairy Res. 59:321-329. https://doi .org/10.1017/S0022029900030594.

Houlihan, A. V., P. A. Goddard, S. M. Nottingham, B. J. Kitchen, and C. J. Masters. 1992b. Interactions between the bovine milk fat globule membrane and skim milk components on heating whole milk. J. Dairy Res. 59:187-195. https://doi.org/10.1017/ S0022029900030430.

Jeanson, S., D. Dupont, N. Grattard, and O. Rolet-Répécaud. 1999. Characterization of the heat treatment undergone by milk using two inhibition ELISAs for quantification of native and heat denatured $\alpha$-lactalbumin. J. Agric. Food Chem. 47:2249-2254. https:// doi.org/10.1021/jf9809232

Kanno, C., M. Shimizu, and K. Yamauchi. 1975. Isolation and physicochemical properties of a soluble glycoprotein fraction of milk fat globule membrane. Agric. Biol. Chem. 39:1835-1842. https://doi .org/10.1080/00021369.1975.10861855.

Kim, D. H., C. Kanno, and Y. Mizokami. 1992. Purification and characterization of major glycoproteins, PAS-6 and PAS-7, from bovine milk fat globule membrane. Biochim. Biophys. Acta Protein Struct. Mol. Enzymol. 1122:203-211. https://doi.org/10.1016/ 0167-4838(92)90325-8.

Korhonen, H. 2009. Milk-derived bioactive peptides: from science to applications. J. Funct. Foods 1:177-187. https://doi.org/10.1016/ j.jff.2009.01.007.

Laemmli, U. K. 1970. Cleavage of structural proteins during the assembly of the head of bacteriophage T4. Nature 227:680-685. https://doi.org/10.1038/227680a0.

Le, T. T., T. Van de Wiele, T. N. H. Do, G. Debyser, K. Struijs, B. Devreese, K. Dewettinck, and J. Van Camp. 2012. Stability of milk fat globule membrane proteins toward human enzymatic gastrointestinal digestion. J. Dairy Sci. 95:2307-2318. https://doi.org/10 $.3168 /$ jds.2011-4947.

Lee, S. J., and J. W. Sherbon. 2002. Chemical changes in bovine milk fat globule membrane caused by heat treatment and homogenization of whole milk. J. Dairy Res. 69:555-567. https://doi.org/10 $.1017 /$ S002202990200571X.

Lopez, C. 2011. Milk fat globules enveloped by their biological membrane: Unique colloidal assemblies with a specific composition and structure. Curr. Opin. Colloid Interface Sci. 16:391-404. https:// doi.org/10.1016/j.cocis.2011.05.007.

Madureira, A. R. T. Tavares, A. M. P. Gomes, M. E. Pintado, and F. X. Malcata. 2010. Invited review: Physiological properties of bioactive peptides obtained from whey proteins. J. Dairy Sci. 93:437-455. https://doi.org/10.3168/jds.2009-2566.

Mayayo, C., M. Montserrat, S. J. Ramos, M. J. Martínez-Lorenzo, M. Calvo, L. Sánchez, and M. D. Pérez. 2014. Kinetic parameters for high-pressure-induced denaturation of lactoferrin in human milk. Int. Dairy J. 39:246-252. https://doi.org/10.1016/j.idairyj.2014.07 .001 .

Nyegaard, S., V. A. Novakovic, J. T. Rasmussen, and G. E. Gilbert 2013. Lactadherin inhibits secretory phospholipase $\mathrm{A}_{2}$ activity on pre-apoptotic leukemia cells. PLoS One 8:e77143. https://doi.org/ 10.1371/journal.pone.0077143.

Pallesen, L. T., L. R. L. Pedersen, T. E. Petersen, and J. T. Rasmussen. 2007. Characterization of carbohydrate structures of bovine MUC15 and distribution of the mucin in bovine milk. J. Dairy Sci 90:3143-3152. https://doi.org/10.3168/jds.2007-0082.

Parrón, J. A., D. Ripollés, M. D. Pérez, M. Calvo, J. T. Rasmussen and L. Sánchez. 2016. Effect of heat treatment on antirotaviral activity of bovine and ovine whey. Int. Dairy J. 60:78-85. https:// doi.org/10.1016/j.idairyj.2016.02.030.

Peterson, J. A., M. Hamosh, C. D. Scallan, R. L. Ceriani, T. R. Henderson, N. R. Mehta, M. Armand, and P. Hamosh. 1998. Milk fat globule glycoproteins in human milk and in gastric aspirates of mother's milk-fed preterm infants. Pediatr. Res. 44:499-506. https://doi.org/10.1203/00006450-199810000-00006.

Phelan, M., A. Aherne, R. J. Fitzgerald, and N. M. O'Brien. 2009. Casein-derived bioactive peptides: Biological effects, industrial uses, safety aspects and regulatory status. Int. Dairy J. 19:643-654. https://doi.org/10.1016/j.idairyj.2009.06.001.

Rasmussen, J. T. 2009. Bioactivity of milk fat globule membrane proteins. Aust. J. Dairy Technol. 64:63-67.

Ripollés, D., J. A. Parrón, M. Calvo, M. D. Pérez, R. J. FitzGerald, and L. Sánchez. 2016. Antioxidant activity of co-products from milk fat processing and their enzymatic hydrolysates obtained with different proteolytic preparations. Int. Dairy J. 60:70-77. https://doi.org/10.1016/j.idairyj.2016.02.031.

Rombaut, R., V. Dejonckheere, and K. Dewettinck. 2006. Microfiltration of butter serum upon casein micelle destabilization. J. Dairy Sci. 89:1915-1925. https://doi.org/10.3168/jds.S0022 -0302(06)72259-7.

Shi, J., and G. E. Gilbert. 2003. Lactadherin inhibits enzyme complexes of blood coagulation by competing for phospholipid-binding sites. Blood 101:2628-2636. https://doi.org/10.1182/blood-2002 $-07-1951$. 
Switzer, R. L., and L. F. Garrity. 1999. Experimental Biochemistry: Theory and Exercises in Fundamental Methods. 3rd ed. W. H. Freeman and Company, New York, NY.

Vanderghem, C., P. Bodson, S. Danthine, M. Paquot, C. Deroanne, and C. Blecker. 2010. Milk fat globule membrane and buttermilks: From composition to valorization. Biotechnol. Agron. Soc. Environ. 14:485-500.

Vanderghem, C., F. Francis, S. Danthine, C. Deroanne, M. Paquot, E. De Pauw, and C. Blecker. 2011. Study on the susceptibility of the bovine milk fat globule membrane proteins to enzymatic hydrolysis and organization of some of the proteins. Int. Dairy J. 21:312-318. https://doi.org/10.1016/j.idairyj.2010.12.006.

Wehbi, Z., M. D. Pérez, L. Sánchez, C. Pocoví, C. Barbana, and M. Calvo. 2005. Effect of heat treatment on denaturation of bovine alpha-lactalbumin: Determination of kinetic and thermodynamic parameters. J. Agric. Food Chem. 53:9730-9736. https://doi.org/ $10.1021 /$ jf050825y.

Wijayanti, H. B., N. Bansal, and H. C. Deeth. 2014. Stability of whey proteins during thermal processing: A review. Compr. Rev. Food Sci. Food Saf. 13:1235-1251. https://doi.org/10.1111/1541-4337 .12105.

Wróblewska, B., and A. Troszyńska. 2005. Enzymatic hydrolysis of cow's whey milk proteins in the aspect of their utilization for the production of hypoallergenic formulas. Pol. J. Food Nutr. Sci. 14:349-357.

Ye, A., J. Cui, and H. Singh. 2011. Proteolysis of milk fat globule membrane proteins during in vitro gastric digestion of milk. J. Dairy Sci. 94:2762-2770. https://doi.org/10.3168/jds.2010-4099.

Ye, A., H. Singh, M. W. Taylor, and S. Anema. 2002. Characterization of protein components of natural and heat-treated milk fat globule membranes. Int. Dairy J. 12:393-402. https://doi.org/10.1016/ S0958-6946(02)00034-1.

Ye, A., H. Singh, M. W. Taylor, and S. Anema. 2004. Interactions of whey proteins with milk fat globule membrane proteins during heat treatment of whole milk. Lait 84:269-283. https://doi.org/10 .1051/lait:2004004.

Zanabria, R., A. M. Tellez, M. W. Griffiths, and M. Corredig. 2014 The antiproliferative properties of the milk fat globule membrane are affected by extensive heating. Dairy Sci. Technol. 94:439-453. https://doi.org/10.1007/s13594-014-0171-8.

Zhang, L., S. Boeren, M. Smits, T. van Hooijdonk, J. Vervoort, and K. Hettinga. 2016. Proteomic study on the stability of proteins in bovine, camel, and caprine milk sera after processing. Food Res. Int. 82:104-111. https://doi.org/10.1016/j.foodres.2016.01.023. 